\title{
IMPLEMENTASI MODEL PEMBELAJARAN PROBLEM BASED LEARNING UNTUK MENINGKATKAN PRESTASI BELAJAR FISIKA
}

\author{
Ni Nyoman Yuniati \\ SMA Negeri 1 Denpasar
}

\begin{abstract}
ABSTRAK
Penelitian ini dilaksanakan di SMA Negeri 1 Denpasar di kelas XI IPA 8 tahun ajaran 2014/2015, yang kemampuan peserta didiknya untuk materi dinamika partikel cukup rendah. Tujuan penulisan penelitian tindakan kelas ini adalah untuk mengetahui apakah model pembelajaran Problem Based Learning dapat meningkatkan prestasi belajar peserta didik. Metode pengumpulan datanya adalah tes prestasi belajar dan aktivitas siswa. Metode analisis datanya adalah deskriptif ,baik untuk data kualitatif maupun untuk data kuantitatif.Hasil yang diperoleh dari penelitian ini adalah Problem Based Learningdapat meningkatkan prestasi belajar peserta didik. Ini terbukti dari hasil yang diperoleh pada awalnya mencapai nilai rata-rata 63,25. Pada siklus I mencapai nilai rata-rata 79,51 dan pada siklus II mencapai nilai rata-rata 85,00.Kesimpulan yang diperoleh dari penelitian ini adalah model pembelajaran Problem Based Learning dapat meningkatkan prestasi belajar Fisika pada materi hukum Newton Tentang Gravitasi.
\end{abstract}

Kata Kunci: Model Pembelajaran Problem Based Learning, Prestasi belajar

\begin{abstract}
This research was conducted at SMA Negeri 1 Denpasar in class XI Science 8 academic year 2014/2015, which the ability of learners regarding the particle dynamics material is quite low.The purpose of writing this class action research is to determine whether the model of Problem Based Learning can improve the performance of learners.Method of data collection is learning achievement test and student activity. The method of data analysis is using Descriptive method for qualitative data and quantitative data.The results which are obtained from this research are the Problem Based Learning can improve the performance of learners. This evident isfound from the results obtained before using Problem Based Learning method reached an average value of 63.25. But the result in the first cycle of using the method reached an average value of 79.51 and the second cycle reached an average value of 85.00.The conclusion from this study is the model of Problem Based Learning can improve learning achievement Physics Newton's laws of matter About Gravity.
\end{abstract}

Keywords: Model of Problem Based Learning, Learning achievement

\section{PENDAHULUAN}

Untuk menghadapi tantangan era globalisasi, diperlukan sumber daya manusia yang memiliki kemampuan berpikir dan intelektual tinggi, yaitu yang mencakup kemampuan penalaran logis, berpikir sistematis, kritis, cermat, dan kreatif, mampu mengkomunikasikan gagasan terutama dalam memecahkan masalah. Namun kenyataan di lapangan menunjukkan bahwa 
pembelajaran fisika yang dilakukan lebih dominan kepada aspek pengetahuan dan pemahaman konsep.Pendekatan pembelajaran yang diimplementasikan di kelas kurang menampakkan prosedur dan struktur kegiatan yang menunjang pendekatan pembelajaran yang berorientasi pada peserta didik aktif dan dibuat aktif, karena tidak menunjukkan tahap-tahap pembelajaran yang memungkinkan peserta didik memperoleh, mengenal, memahami, dan mengaplikasikan konsep secara bermakna. Untuk itu, diperlukan pengembangan model pembelajaran yang dapat menumbuhkembangkan kemampuan berpikir kritis dan meningkatkan pemahaman konsep peserta didik.Masalah- masalah dalam meningkatkan pemahaman konsep yang sering muncul berdasarkan pengalaman penulis dalam mengelola pembelajaran di kelas XI IPA8 SMA Negeri 1 Denpasar tahun pelajaran 2014/2015 antara lain : 1) aktivitas peserta didik dalam mengikuti proses pembelajaran fisika kurang aktif, hal tersebut dibuktikan dengan rendahnya kontribusi peserta didik saat proses pembelajaran berlangsung.dan hanya sepertiga dari jumlah peserta didik dalam kelas tersebut yang dapat menganalisis permasalahan yang diberikan. Sebagian peserta didik kurang mau menyiapkan diri dalam belajar, kurang berani mengemukakan pendapat, kurang berani mengajukan gagasan . 2) Nilai hasil belajar peserta didik di kelas tersebut menunjukkan hasil dibawah kriteria ketuntasan minimum (KKM) yang ditetapkan. Jika hal tersebut dibiarkan tentu peserta didik yang tidak mampu akan terbelakang yang akhirnya akan berdampak pada makna belajar dan ketercapaian hasil belajar peserta didik tidak maksimal. Salah satu upaya yang dilakukan guru untuk mengatasi masalah yang telah diuraikan didepan yaitu Pembelajaran berbasis masalah ( Problem Based Learning PBL).PBL dikembangkan untuk membantu peserta didik mengembangkan kemampuan berpikir, pemecahan masalah, dan keterampilan intelektual; belajar berbagai peran orang dewasa melalui pelibatan mereka dalam pengalaman nyata atau simulasi; dan menjadi pebelajar yang otonom dan mandiri (Ibrahim dalam Trianto.2007).Melihat adanya kesenjangan antara harapan dengan kenyataan yang ada di lapangan seperti yang sudah dipaparkan diatas, maka rumusan penelitian ini dapat disampaikan sebagai berikut:

Apakah Problem Based Learning mampu meningkatkan aktivitas dan prestasi belajar peserta didik kelas XI IPA8 SMA Negeri 1Denpasar Tahun Pelajaran 2014/2015 ?.Berdasarkan rumusan masalah diatas, tujuan yang ingin dicapai pada penelitian ini adalah:Untuk meningkatkan aktivitas dan prestasi belajar peserta didik kelas XI IPA8 SMA Negeri 1Denpasar Tahun Pelajaran 2014/2015.Secara teoritis, hasil penelitian ini diharapkan akan bermanfaat sebagai acuan dalam memperkaya teori dalam rangka peningkatan kompetensi guru.

Menurut Piaget (Dimyati dan Mudjiono, 2002: 15) pembelajaran terdiri dari empat langkah, yaitu: menentukan topik yang dapat dipelajari oleh anak sendiri, memilih atau mengembangkan aktivitas kelas dengan topik tersebut, mengetahui adanya kesempatan bagi guru untuk mengemukakan pertanyaan yang menunjang proses pemecahan masalah, dan menilai 
pelaksanaan tiap kegiatan, memperhatikan, dan melakukan revisi. Proses membantu peserta didik untuk membangun konsep atau prinsip dengan kemampuannya sendiri melalui proses internalisasi disebut pembelajaran.

Djamarah (1994:23) mendefinisikan prestasi belajar sebagai hasil yang diperoleh berupa kesan-kesan yang mengakibatkan perubahan dalam diri individu sebagai hasil dari aktivitas dalam belajar.Kalau perubahan tingkah laku adalah tujuan yang mau dicapai dari aktivitas belajar, maka perubahan tingkah laku itulah salah satu indikator yang dijadikan pedoman untuk mengetahui kemajuan individu dalam segala hal yang diperolehnya di sekolah. Dalam pembahasan dibicarakan mengenai prestasi belajar sebagai hasil penilaian danterkait dengan penelitian ini, untuk mengukur prestasi belajar fisika digunakan tes hasil belajar, dengan mengacu pada materi pelajaran gravitasi pada Kurikulum Tingkat Satuan Pendidikan (KTSP) yang berlaku di sekolah ini.

\section{METODE PENELITIAN}

Penelitian dilaksanakan di kelas XI IPA8 yang merupakan kelas akselerasi SMA Negeri 1Denpasar pada semester ganjil tahun pelajaran 2014/2015. Penelitian ini dilakukan dari bulan September sampai dengan Desember 2014. Untuk mengumpulkan data dalam penelitian ini digunakan tes prestasi belajar Fisika yang disusun berdasarkan materi yang disajikan.Untuk aktivitas belajar menggunakan lembar observasi. Metode yang digunakan untuk menganalisis data hasil penelitian ini adalah metode deskriptif.Instrumen yang digunakan untuk menilai prestasi belajar Fisika siswa kelas XI IPA-8 adalah tes prestasi belajar Fisika untuk siklus 1 dan siklus 2 yang merupakan soal obyektif dengan 5 pilihan jawaban. Dalam penelitian ini diusulkan tingkat prestasi belajar siswa mencapai nilai rata-rata 80 dengan ketuntasan belajar secara klasikal sebesar $85 \%$. Sedangkan untuk aktivitas belajar siswa mencapai skor minimal berada pada kategori cukup aktif dengan skor 1,835 $<\mathrm{X} \leq 2,165$.

Untuk penelitian ini penulis memilih rancangan penelitian tindakan yang dikemukakan oleh Mc. Kernan.

\section{HASIL PENELITIAN DAN PEMBAHASAN}

Data awal yang diperoleh dengan ratarata $63,25 \%$ ini menunjukkan bahwa kemampuan peserta didik dalam mata pelajaran fisika masih sangat rendah mengingat kriteria ketuntasan belajar peserta didik untuk mata pelajaran ini di SMA Negeri 1 Denpasar adalah 80\%.Dengan nilai yang sangat rendah seperti itu maka peneliti mengupayakan untuk dapat meningkatkan prestasi belajar peserta didik menggunakan model PBL. Akhirnya dengan penerapan model PBL yang benar sesuai teori yang ada, peningkatan rata-rata prestasi belajar peserta didik pada siklus I dapat diupayakan dan mencapai rata-rata $79,51 \%$. Namun rata-rata tersebut belum maksimal karena hanya 23 orang dari 31 orang peserta didik seluruhnya memperoleh nilai di atas KKM sedangkan yang lainnya yaitu 8 orang belum mencapai KKM. Sedangkan prosentase ketuntasan belajar mereka baru mencapai 74\%.Hal tersebut terjadi akibat penggunaan model PBL belum maksimal dapat dilakukan 
disebabkan penerapan model tersebut baru dicobakan sehingga guru masih belum mampu melaksanakannya sesuai alur teori yang benar.

Pada siklus ke II perbaikan prestasi belajar peserta didik diupayakan lebih maksimal dengan peneliti membuat perencanaan yang lebih baik, menggunakan alur dan teori dari model PBL dengan benar dan lebih maksimal.Peneliti giat memotivasi peserta didik agar giat belajar, memberi arahan-arahan, menuntun mereka untuk mampu menguasai materi pelajaran pada mata pelajaranfisika lebih optimal. Akhirnya dengan semua upaya tersebut peneliti mampu meningkatkan prestasi belajar peserta didik pada siklus II menjadi rata-rata 85\% dengan ketuntasan $100 \%$. Upaya-upaya yang maksimal tersebut menuntun kepada penelitian bahwa implementasi model PBL mampu meningkatkan prestasi belajar peserta didik.Untuk aktivitas pembelajaran pada siklus I ada peningkatan peran aktif dalam kegiatan pembelajaran.Skor rata-rata aktivitas siswa yang diperoleh pada siklus I berada pada kategori kurang aktif dengan skor rata-rata 1,78 menjadi cukup aktif pada siklus II dengan skor 2,01. Hal ini menunjukkan bahwa ada perbaikan proses walaupun masih kurang. Semua itu disebabkan antara lain: siswa selalu diberitahu agar siswa selalu bekerja dalam kelompoknya, melakukan interaksi dengan teman, interaksi yang terjadi antara siswa dengan guru, siswa yang bertanya dan kegiatan dalam memecahkan masalah.

Berdasarkan hasil yang diperoleh secara umum penelitian ini dapat menjawab permasalahan dan tujuan yang diharapkan yaitu : 1). dapat meningkatkan aktivitas belajar siswa dan 2) dapat meningaktkan dari prestasi belajar. Tidak hanya itu siswa menemukan pengetahuan yang dibangun sendiri dan peranan guru sebagai fasilitator dapat ditingkatkan.

Tabel 1. Rekap Data awal, siklus 1dan siklus 2

\begin{tabular}{llll}
\hline $\begin{array}{l}\text { Data } \\
\text { penelitian }\end{array}$ & $\begin{array}{l}\text { Data } \\
\text { awal }\end{array}$ & Siklus 1 & $\begin{array}{l}\text { Siklus } \\
2\end{array}$ \\
\hline $\begin{array}{l}\text { Prestasi } \\
\text { belajar }\end{array}$ & $63,25 \%$ & $79,51 \%$ & $85 \%$ \\
\hline $\begin{array}{l}\text { Aktivitas } \\
\text { belajar }\end{array}$ & 1,76 & 1,78 & 2,01 \\
\hline Ketuntasan & $25,81 \%$ & $74 \%$ & $100 \%$ \\
\hline
\end{tabular}

Penyajian Prestasi belajar data awal ,siklus 1 dan siklus 2 dalam bentuk grafik/histogram

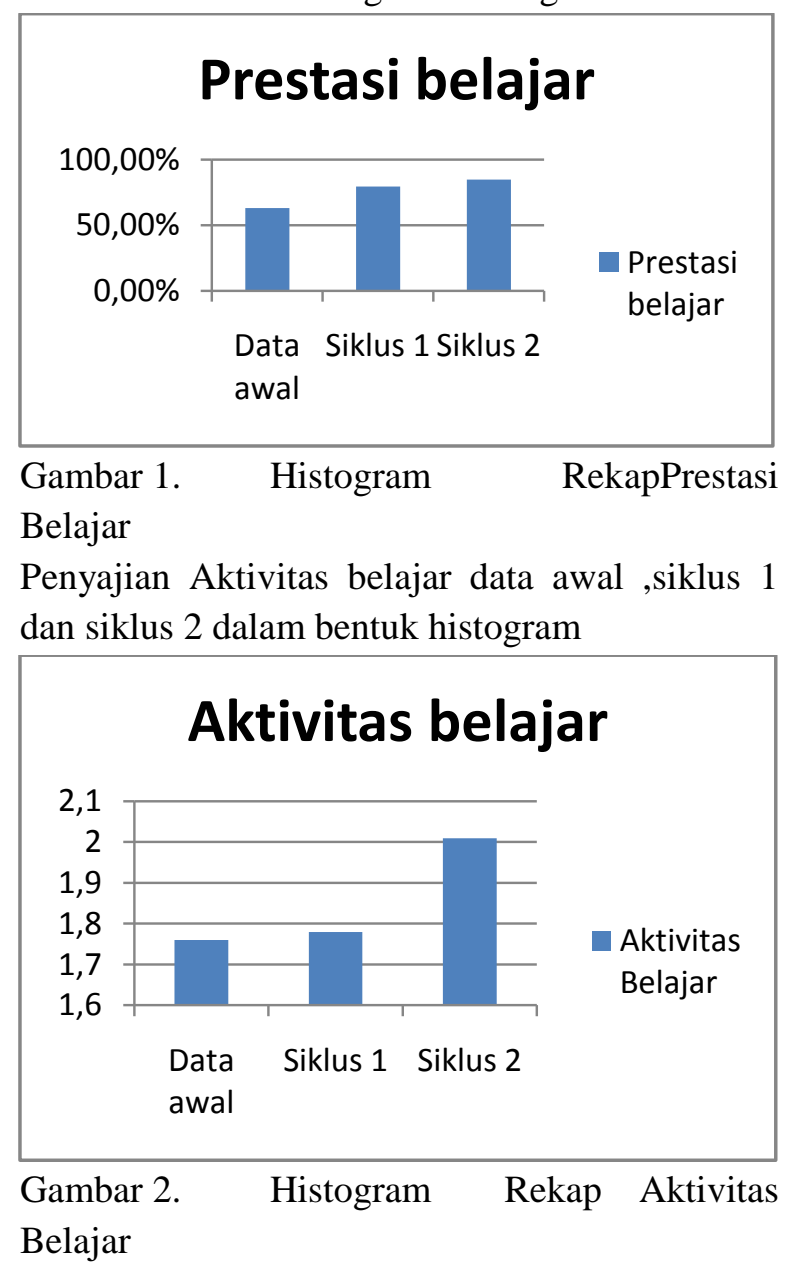




\section{SIMPULAN DAN SARAN}

Bertitik tolak dari pemicu rendahnya prestasi belajar ada pada faktor-faktor seperti model yang digunakan guru, sehingga penggunaan atau penggantian model diperlukan, akibatnya peneliti mencoba model pembelajaran Problem Base Learning dalam upaya untuk dapat memecahkan permasalahan yang ada.

Kenaikan prestasi belajar peserta didik dapat dilihat dari bukti-bukti berikut:

a. Dari data awal ada 23peserta didik mendapat nilai dibawah KKM dan pada siklus I menurun menjadi 8peserta didik dan siklus II seluruhpeserta didik mendapat nilai di atas KKM.

b. Dari rata-rata awal $63,25 \%$ naik menjadi $79,51 \%$ pada siklus I dan pada siklus II naik menjadi $85 \%$.

c. Dari data awal peserta didik yang tuntas hanya 8 orang sedangkan pada siklus I menjadi lebih banyak yaitu 23orangpeserta didik dan pada siklus II seluruhpeserta didik tuntas.

Kenaikan aktivitas siswa dapat dilihat dari bukti-bukti berikut :

a. Penerapan model pembelajaran Problem Based Learning dalam pembelajaran fisika di kelasXI IPA 8 SMA Negeri 1 Denpasar dapat meningkatkan aktivitas siswa dari kategori kurang menjadi cukup aktif.

b. Penerapan model pembelajaran Problem Based Learning dalam pembelajaran fisika di kelas XI IPA 8 SMA Negeri 1 Denpasar dapat meningkatkan prestasi belajar dari belum tuntas menjadi tuntas.

Berdasarkan semua data pendukung pembuktian pencapaian tujuan pembelajaran dapat disampaikan bahwa model pembelajaran Problem Based Learning /PBL dapat memberi jawaban yang diharapkan sesuai tujuan penelitian ini. Semua ini dapat dicapai adalah kesiapan dan kerja keras peneliti dari sejak pembuatan proposal,review hal hal yang belum bagus bersama teman -teman guru, penyusunan kisi-kisi dan instrument penelitian,penggunaan sarana triangulasi data sampai pada pelaksanaan penelitian yang maksimal.

\section{DAFTAR PUSTAKA}

Arikunto, Suharsimi. 1995. DasarDasarEvaluasiPendidikan. Jakarta: BumiAksara.

Arikunto, Suharsimi; Suhardjono; Supardi. 2006. PenelitianTindakanKelas. Jakarta: PT BumiAksara.

Badan Standar Nasional Pendidikan. 2007. Peraturan Menteri Pendidikan Nasional Republik Indonesia Nomor 41 Tahun 2007. Jakarta: BSNP.

Dahar, R. W. 1989. Teori-teoriBelajar. Jakarta: Erlangga.

Depdiknas,2002c. KurikulumBerbasisKompetensi. PuskurBalitbang. 
Depdiknas, 2003a.Standar Kompetensi Mata PelajaranFisika. Jakarta.

DimyatidanMudjiono.

2001.

BelajardanPembelajaran. Jakarta: DirjenDikti.

Djamarah, $\quad$ SyafulBahri. 2002. PrestasiBelajardanKompetensiGuru. Surabaya: Usaha Nasional.

Ibrahim, M. dan Mohamad Nur. 2000. PengajaranBerdasarkanMasalah. Pusat Sains dan Matematika Sekolah. Program PascasarjanaUNESA:University Press.

Nurkancana, W dan Sunartana .1992. Evaluasi hasil belajar .Surabaya : Usaha Nasional.
Sadia.2003a.

StrategiPembelajaranBerorientasiKur ikulumBerbasisKompetensi.Makalah Disajikanpada Seminar PeningkatanProfesionalisme GuruGuru SMP Negeri 3 SingarajadalamMenyongsong $K B K$ 2003 Tanggal 26 Januari 2003.

Sadia.2003b. Konstruktivisme DalamBelajar dan Mengajar.Materi Perkuliahan Program S2 Manajemen Pendidikan dan S2 Penelitian dan Evaluasi Pendidikan.

Sardiman, A.M. 1988. Interaksi dan Motivasi Belajar-MengajarPedoman bagi Guru dan Calon Guru.Jakarta: Rajawali Pers. 